\title{
A Review of Technology and Products Supporting E- Learning System
}

\author{
Yanping Liu and Ying Wang \\ School of Economics and Management, Beijing Jiao Tong University, Beijing100044, \\ P.R.China mf001455@263.net wywywy0511@sina.com
}

\begin{abstract}
With the development of modern information technology and the increases of demand for building and maintaining ongoing capabilities, elearning has played more and more important role of all the technologies in the supporting knowledge management. A successful e-learning system is supported by many critical success factors and technology has become the key factor among these factors. Consequently, the review of basic technologies and corresponding products that support e-learning will be in favor of further study on e-learning. This paper generalizes the advanced technologies and products that support the design and operation of e-learning system. At the end of this paper, we analyze the main trends of the development direction of e-learning technology.
\end{abstract}

Keywords: E-learning, Knowledge management, Products, Technology

\section{INTRODUCTION}

Knowledge Management, is nothing new, but instead is newly practices and has become the most prevalence method to enhance the learning capabilities of organizations and organizational members [1]. Many technologies can be used to support knowledge management system, such as business intelligence, collaboration and e-learning. As the demand for building and maintaining ongoing capabilities increases, e-learning has played more and more important role of all the technologies in the supporting process of knowledge management. Thus, it is urgent for researchers to pay more attention to the theory and technologies development of e-learning.

E-learning system as a just-in-time training delivery system need much help from modern techniques and tools to accomplish the delivery of information. Researchers proposed many advanced technologies and products to support the design and operation of e-learning. So this paper tries to make a literature review of these technologies and corresponding products from the perspective of knowledge management. Based on the review, we put forward the main trends of the development direction of e-learning technology.

Please use the following format when citing this chapter:

Liu. Y., Wang. Y., 2007. in IFIP International Federation for Information Processing. Volume 254. Research and Practical Issues of Enterprise Information Systems II Volume 1. eds. L. Xu. Tjoa A.. Chaudhry S. (Boston: Springer). pp. 513-518. 


\section{LITERATURE REVIEW OF TECHNOLOGY AND PRODUCT SUPPORTING E-LEARNING SYSTEM}

\subsection{Review of the Development of Technology Supporting E-Learning System}

A successful e-learning system is supported by several critical success factors (CSFs) and technology has become the key factor among the CSFs. Different scholars put forward different information technologies to design and support e-learning system. There technologies enhance the learning efficiency and develop the knowledge management of organization. We summarize the basic technologies that playing important role in e-learning system design and operation in Table 1.

Table 1. Development of Information Technologies of E-Learning

\begin{tabular}{|c|c|c|}
\hline Technology & Presenter & Proposed Year \\
\hline DHTML & Pellegrino, Goldman[2] & 1999 \\
\hline VRML & Janet Johns[3] & 2000 \\
\hline Portals & Brandon Hall[4] & 2000 \\
\hline KnowledgeTree & $\begin{array}{l}\text { Peter Brusilovsky, Hemanta Nijhavan } \\
\text { [5] }\end{array}$ & 2002 \\
\hline LiveNet & Quang Vinh Nguyen [6] & 2004 \\
\hline Ajax & Jesse James Garrett [7] & 2005 \\
\hline E-dap & Bonastre [8] & 2005 \\
\hline $\begin{array}{l}\text { Central } \\
\text { system }\end{array}$ LASAR & Andre Luiz[9] & 2007 \\
\hline CAT & Mu-Jung Huang[10] & 2007 \\
\hline
\end{tabular}

From Table 1we can see that the technologies developed for e-learning system are mainly information technologies. Information technologies have become the most important technology for the development and operation of e-learning system. How to make full use of these information technologies for the establishment and operation of e-learning system will become one of the most important strategies for all organizations that engaged in the promotion of learning capability. 


\subsection{Review of Products Supporting E-Learning System}

Successful operation of an e-learning system needs products to transfer knowledge to members of organization. There are many products supporting e-learning and Table 2 captures main examples. The products proposed by different scholars to support elearning system are mainly developed on the basis of information technologies. The function of these products to e-learning system is similar as the function of software to computer. These products make the delivery and share of knowledge in organization come true.

Table 2. Products Supporting E-Learning System [11-12]

\begin{tabular}{|c|c|}
\hline Product & Description \\
\hline $\begin{array}{l}\text { Linux Operating } \\
\text { system }\end{array}$ & $\begin{array}{l}\text { The product is object-oriented projected to be easily } \\
\text { customized for each type of Linux system installation. This } \\
\text { product was made using the facilities of IDE Delphi. }\end{array}$ \\
\hline Product & Description \\
\hline E-Learning Suite & $\begin{array}{l}\text { The elearning suite, consisting of e-learning and Siebel } \\
\text { Distance Learning, provides automated content management, } \\
\text { methods of measuring learning, and course content delivery. }\end{array}$ \\
\hline $\begin{array}{l}\text { Vuepoint } \\
\text { Learning System } \\
3.0\end{array}$ & $\begin{array}{l}\text { Four modules make up this e-learning and content } \\
\text { management system: a Web-based evaluation, teaching, and } \\
\text { research tool; a student testing and course tracking program; a } \\
\text { template-based content creator; and an off-line viewer for } \\
\text { asynchronous learning. }\end{array}$ \\
\hline $\begin{array}{l}\text { Human Capital } \\
\text { Management } \\
\text { Suite }\end{array}$ & $\begin{array}{l}\text { The suite includes trademark KP, Performance, KP } \\
\text { Learning, and KP Content. Learners can create customized } \\
\text { blended online learning curricula. Products test and track } \\
\text { learner progress and activities. }\end{array}$ \\
\hline TrainNet & $\begin{array}{l}\text { It integrates full-screen video with live interaction, using } \\
\text { audio conferencing, synchronized Web content, application } \\
\text { sharing, embedded email, and whiteboard and Q\&A features. }\end{array}$ \\
\hline
\end{tabular}

\section{THE TECHNOLOGY DEVELOPMENT TRENDS OF E- LEARNING SYSTEM}

The review brings us a scene of the actuality of e-learning theory and application. Because of the fast change and complication of market environment, any changes of a 
slight factor may become the important reason of success or failure of e-learning system. To promote learning efficiency and learning ability of organization, we must consider every factor that supports the operation of e-learning system and integrate synthetically many kinds of technologies and means. By integrating different kinds of technologies, every key element in the e-learning system will coordinate and will give play to its greatest benefit [13]. So integration of different information technologies and integration of information technology with other technologies will be basic direction of e-leaning technology development.

\subsection{Development of Technology Integrating Knowledge Management with E- Learning System}

Although e-learning system and knowledge management have their unique characteristics, the relationship between them has become more and more closed. Many scholars have found that the emphasis on e-learning has become shifting to "performance support" with the integration of Knowledge Management capabilities [14]. With the highly competitive and dynamic environment, the integration of knowledge and e-learning system has become the critical requirement of improving the learning and innovation capability of organization. E-learning users need a suitable knowledge management system to obtain correct and complete information they need. Knowledge management system needs an advanced e-learning system to help it realize the effective transmission of knowledge. Therefore, the technologies and products that integrate knowledge management and e-learning will be the urgent need for the development of e-learning.

\subsection{Development of Collaborative E-Learning Technologies}

Collaborative technologies will improve the operability of e-learning system and accelerate the generalization of e-learning system. So a great many owners turn their focus on how to build up a more perfect learning environment for collaborative elearning. Collaborative e-learning includes man-machine interactions and man-man interactions. Compared with the development of man-machine interaction technology, man-man interactions need more rapid development. Because of the defects of elearning system, such as lack of interpersonal communication, baldness and aridity, interpersonal communication has become an important direction for e-learning. Collaborative technologies and products that improve interpersonal communication in e-learning system will be one basic trend of the development of e-learning.

\subsection{Combination of Technical Domination and Technical Assistant}

Technical domination and technical assistant are two basic views about the development direction of e-learning since the birth of e-learning. In the term of the nature of e-learning, an effective e-learning is not decided by whether it is a technical domination or a technical assistant. In terms of characteristics of learning content, the 
e-learning platform of technical domination more suits for explicit, cognitive and technical knowledge, while the e-learning platform of technical assistant more suits for an academic or soft technology one. A learner no matter where he is-in an enterprise or college-needs both of these two learning modes. Thus a platform that combine the views of technical domination and technical assistant is a promising one that accords with the develop trend of e-learning platform.

\section{CONCLUSIONS}

This paper makes a review about advanced technologies and products that support the design and operation of e-learning system. With these reviews of e-learning, we find that more theory about technology and corresponding products is needed to guide the design, delivery, and implementation of e-learning. At the end of this paper, we analyze the main trends of the development direction of e-learning technology. With the development of information technology, we believe that more advanced technologies and more effective products that support e-learning will be put forward. E-learning will have a very promising future in the new millennium.

\section{REFERENCES}

1. M.T. Hansen, N. Nohria, and T. Tierney, What's your strategy for managing knowledge? Harvard Business Review. Volume 77, Number 2, pp.106-116, (1999).

2. J.W. Pellegrino and S.R. Goldman, The new languages, Training and Development. Volume 53, Number 8, pp.35-46, (1999).

3. T. Barron, The future of digital learning, E-learning. Volume 1, Number 2, pp.46-57, (2000).

4. T.L. Wentling, C. Waight, J. Gallaher, J.L. Fleur, C. Wang, and A. Kanfer, E-learning-A Review of Literature, Knowledge and Learning Systems Group. Volume 6, Number 9, pp.37-51, (2000).

5. P. Brusilovsky and H. Nijhavan, A framework for adaptive e-Learning based on distributed re-usable learning activities, in Proc. of World Conference on E-Learning (AACE, Canada, 2002), pp.154-161.

6. Q.V. Nguyen, M. Huang, and I. Hawryszkiewycz, A new visualization approach for supporting knowledge management and collaboration in e-Learning, in Proc. of the Eighth International Conference on Information Visualisation (Computer Society: London, England, 2004), pp.693-700.

7. J.J. Garrett, Ajax: A New Approach to Web Applications, Adaptive Path (2005). http://www.35dx.com/html/web/1/web386.html (Accessed July 8, 2007).

8. O.M. Bonastre, A.P. Benavent, and M.A. Ortuno, E-dap: An e-learning tool for Managing, Distributing and Capturing Knowledge, in Proc. of ITHET 6th Annual International Conference, eds. J. Dolio (IEEE: Dominican Republic, 2005), pp.S3B1115 .

9. A.L.M. Oliveira and C.A. Schneider, Metrology on-the-job e-learning through remote services, Measurement. Volume 40, Number 7, pp.183-191, (2007). 
518 Yanping Liu and Ying Wang

10. M. Huang, H. Huang, and $M$. Chen, Constructing a personalized e-learning system based on genetic algorithm and case-based reasoning approach, Expert Systems with Applications. Volume 33, Number 5, pp.551-564, (2007).

11. B. Marshall, E. Zhang, H. Chen, A. Lally, R. Shen, E. Fox, and L.N. Cassel, Convergence of knowledge management and e-learning: the GetSmart experience, IEEE (2006). http://ieeexplore.ieee.org/ie15/8569/27127/01204907.pdf?armumber=1204907 (Accessed July 10, 2007).

12. M.E. Jennex, Case studies in knowledge management (Idea Group Inc Publishing: New York, NY, 2005).

13. S. Liu and G. Xiang, Research on the Integration of Knowledge Management and ELearning, Modern Educational Technology. Volume 14, Number 4, pp.10-14, (2004).

14. A. Sadler, The future of e-learning: an expanding vision, IBM MindSpan (2001). http://www-3.ibm.com/software/mindspan/distlmg.nsf (Accessed June 10, 2007). 